\title{
Levels of training indicators in the annual training of young hockey players
}

\author{
Marcelina Nowakowska ${ }^{1}$, Tomasz Gabrys' ${ }^{2}$, Mariusz 0zimek³ \\ Arkadiusz Stanula ${ }^{4}$, Urszula Szmatlan-Gabrys ${ }^{5}$ \\ ${ }^{1}$ Institute of Physical Education and Sport, State School of Higher Education in Oswiecim, Poland \\ ${ }^{2}$ Pedagogical Department, The Jan Dlugosz University in Czestochowa, Polska \\ ${ }^{3}$ Department of Track end Fields Sports, Institute of Sport, University School of Physical Education in Cracow, \\ Poland \\ ${ }^{4}$ Department of Sports Training, The Jerzy Kukuczka Academy of Physical Education in Katowice, Poland \\ ${ }^{5}$ Department of Anatomy, University School of Physical Education Cracow, Poland
}

\begin{abstract}
Abstrakt
This paper presents the means of control used in a competitive sport (ice hockey), including changes in aerobic and anaerobic capacity indicators between training periods.

The study was carried out with 14 ice-hockey players $(n=14)$, pupils at the Sport Championship School run by the Polish Ice Hockey Federation in Sosnowiec. All tests were performed in the early general preparation period (June), in the early competition period (November), and during the direct preparation period (March) directly for the main sporting event of the season - the Ice Hockey U-18 World Championship Division I Group B.

The values of three of the four aerobic capacity indicators were the lowest in the direct preparation period and the highest in the early competition period. The fact that the values of all anaerobic capacity indicators were the highest in the direct preparation period indicates that the study participants were well prepared for the specific demands of on-ice competition.
\end{abstract}

Key words: ice hockey, training, aerobic and anaerobic capacity

\section{INTRODUCTION}

Research shows that the energy expanded by a hockey player during a game comes from anaerobic metabolism (69\%) and aerobic metabolism [Geithner et al. 2006, Vescovi et al. 2006a, Noonan 2010, Ransdel et al. 2013]. The main source of energy enabling anaerobic work is anaerobic lactate metabolism [Carey i wsp. 2007, Leone et al. 2007, Gabrys et al. 2009, Durocher et al. 2010] that involves oxygen debt of up to 8.5-9.61 and blood lactate concentration amounting to $18 \mathrm{mmolxl}^{-1}$ (60-75\% of its maximum level). High anaerobic capacity supplemented by mainly aerobic metabolism is a prerequisite for players to be able to perform during a game with the highest intensity when only short rest breaks are allowed. Therefore, the ultimate purpose of anaerobic and aerobic training for ice-hockey players should be to ensure their maximum effectiveness on ice [Burr et al. 2008, Durocher et al. 2010].

In Poland, training for ice-hockey players evolves under the influence of several factors, two of which have effect on the training of all groups of players. The first of them is the growing availability of training facilities, including artificial ice rinks, and the second one has to do with an increasing number of games played during the season, a typical trend in the league competition in the top ice-hockey countries. Both factors have caused that excluding a 6-8 week rest period the training process practically goes on all year round, from mid-June to mid-March [Battochio et al. 2009, Matthews et al. 2010]. The annual training cycle is divided into four sub-periods, the most important of which is the 6-month competition period (tab. 6). The other three periods are 
intended to prepare players for a long competition period and to ensure a consistently high quality of their performance [Szmatlan-Gabrys 2007, Durocher et al. 2008].

The annual training cycle starts with a general conditioning period which runs from mid-May to mid-June. Its main goal is to improve players' general physical fitness and basic motor abilities.

In the early phase of the period, high-volume / low intensity training (zone 2) is applied. The preferred type of strength training involves low-load / high-repetition exercises of gradually rising intensity and speed. The proportion of exercises engaging aerobic-anaerobic metabolism and anaerobic lactate metabolism is increased. The character of strength training changes towards the development of explosive power. With each successive microcycle, the number of training units oriented to speed strength is increased [Metthews et al. 2010, Borek 2011, Gilenstam et al. 2011]. At mid-July, the special preparation period begins, which ends around mid-September.

The second part of the period is focused on pre-competition training and usually contains three mesocycles [Durocher et al. 2008, Matthews et al. 2010, Nowakowska et al. 2017]:

- a 2- to 3-week introductory mesocycle with a training programme similar to that employed in the general preparation period (high-volume training of low to moderate intensity aimed to improve players' general and sport-specific skills).

- a 4- to 6-week special preparation mesocycle with mostly on-ice training. Two training sessions lasting respectively $120 \mathrm{~min}$ (morning) and $90 \mathrm{~min}$ (afternoon) are held daily. The first two weeks are dedicated to high-volume training. To improve players' physical conditioning, set pieces are repeated. The number of speed-building training units gradually increases and on-ice training is enhanced by explosive power training.

- a 2- to 4-week pre-competition mesocycle aimed to improve players' technical and tactical skills and ability to perform tasks during a game. At the top of the training agenda there are exercises developing athletes' skating technique and game tactics. A training game is phased in as a skill-improving exercise and then used during most afternoon training sessions. Exercises improving the use and awareness of defence and attack systems are emphasised. In the last two weeks of the mesocycle, training volume goes up and its intensity is reduced.

- a pre-competition period that is focused on teaching tactics and enhancing players' technique, ensuring that their motor abilities are at a consistently high level, shaping their mental characteristics, and making the team ready for a string of games. Because of frequent rest breaks the intensity of a training unit is moderate. Only two of the weekly training units are characterised by high intensity of exercise. Most training units last from 60 to $90 \mathrm{~min}$ and are performed on ice. Physical conditioning is designed to build players' speed and speed strength through repetitive and interval exercises.

- a transitory period beginning with the end of the competition period that aims to help players recover mentally and physically. Training intensity and volume are reduced in favour of active rest. On-ice training is replaced by team games and other complementary sports. The transitory period is the time for offsetting the impacts of overstrain and injuries.

This paper presents the means of control used in a competitive sport (ice hockey), including changes in aerobic and anaerobic capacity indicators between training periods.

\section{MATERIAL AND METHODS}

The study was carried out with 14 ice-hockey players $(n=14)$, pupils at the Sport Championship School run by the Polish Ice Hockey Federation in Sosnowiec (age 17,77 $\pm 1,25$, body high $181,28 \pm 6,51$, body mass $78,89 \pm 6,12$ ). 
The tests were performed in the early general preparation period (June), in the early competition period (November), and during the direct preparation period (March) for the main sporting event of the season - the Ice Hockey U-18 World Championship Division I Group B.

In Poland, the annual training cycle for ice hockey is divided [Borek 2011, Nowakowska et al. 2017] into:

- a general preparation period with comprehensive off-ice training in the months May to June (8-10 weeks, 980-100 hrs);

- a special preparation period with comprehensive off-ice training from July to September (7-8 weeks);

- a competition period focused on specialist training for the Junior World Championship in April between October and March (28-30 weeks, 220-250 hrs, 8-12 games);

- a general preparation period with comprehensive off-ice training in May (2 weeks).

a) Aerobic capacity measurements

Aerobic capacity was measured in the study participants during an incremental exercise test performed following a protocol with " $n$ " increments. Each of the first three loads (1.5, 2.25 and $3 \mathrm{~W} / \mathrm{kg}$ ) was lasted 2 minutes. All load increases applied between the next four 1-minute steps had the same value of $0.5 \mathrm{~W} / \mathrm{kg}$ [Vescovi 2006a]. The test was carried out on the Cyclus 2 ergometer (Germany), the handlebar of which was adjusted for each subject and the saddle height was set to $104 \%$ of subject's leg length. The following indicators were measured: maximum oxygen uptake - $\mathrm{VO}_{2 \max }[\mathrm{ml} / \mathrm{kg} / \mathrm{min}]$; heart beat frequency - $\mathrm{HR}[\mathrm{bpm}]$; minute ventilation - VE [1/min], total work - Wtot $[\mathrm{J} / \mathrm{kg}]$.

b) Anaerobic capacity measurements

Participants' anaerobic capacity was measured using the Wingate test, which was applied according to its original protocol [Bar-Or 1981]. Exercise load was set to either 8\% (16-yearolds) or $9 \%$ (17-18 year-olds) of the player's body mass [Szmatlan-Gabrys 2007]. The testing device was the Cyclus 2 ergometer again, which automatically adjusted workload as $100 \mathrm{rpm}$ was reached.

The values of the following indicators were recorded: maximal power - Pmax [W, W/kg]; total work - Wtot $[\mathrm{J} / \mathrm{kg}]$.

\section{RESULTS}

The data in fig. 1 and tab. 1, 2 show that participants' $\mathrm{VO}_{2 \max }$ was the highest in the early competition period (November) - $66.8[\mathrm{ml} / \mathrm{kg} / \mathrm{min}]$. By June, its level declined to $62[\mathrm{ml} / \mathrm{kg} / \mathrm{min}]$ and reached its lowest value in the run-up to the key sporting event of the season (the World Championship) $-60.4[\mathrm{ml} / \mathrm{kg} / \mathrm{min}]$. The second and third values are statistically significantly different $(\mathrm{p}=0.005)$. 
Table 1: Changes in the statistical parameters between training periods

\begin{tabular}{|l|c|c|c|}
\hline \multirow{2}{*}{ Parameter } & \multicolumn{3}{|c|}{ Training period } \\
\cline { 2 - 4 } & 1. June & 2. October & 3. March \\
\cline { 2 - 4 } & mean \pm SD & mean \pm SD & mean \pm SD \\
\hline $\mathrm{VO}_{2 \max }[\mathrm{ml} / \mathrm{kg} / \mathrm{min}]$ & $62,36 \pm 5,75$ & $66,79 \pm 6,20$ & $60,43 \pm 5,08$ \\
\hline $\mathrm{HR}_{\max }[\mathrm{bp} / \mathrm{min}]$ & $193,64 \pm 4,38$ & $196,21 \pm 5,79$ & $188,00 \pm 6,99$ \\
\hline $\mathrm{VE}[1 / \mathrm{min}]$ & $154,93 \pm 15,68$ & $161,00 \pm 11,92$ & $154,71 \pm 11,47$ \\
\hline $\mathrm{W}_{\text {tot }}[\mathrm{J} / \mathrm{kg}]$ & $125,27 \pm 11,80$ & $126,39 \pm 13,18$ & $136,23 \pm 17,63$ \\
\hline $\mathrm{P}_{\text {max }}[\mathrm{W}]$ & $988,12 \pm 141,49$ & $1037,51 \pm 133,42$ & $1070,73 \pm 108,71$ \\
\hline $\mathrm{P}_{\max }[\mathrm{W} / \mathrm{kg}]$ & $13,14 \pm 1,13$ & $13,70 \pm 0,96$ & $14,15 \pm 2,04$ \\
\hline $\mathrm{W}_{\text {tot }}[\mathrm{W} / \mathrm{kg}]$ & $301,43 \pm 21,88$ & $311,86 \pm 26,13$ & $348,43 \pm 59,56$ \\
\hline
\end{tabular}

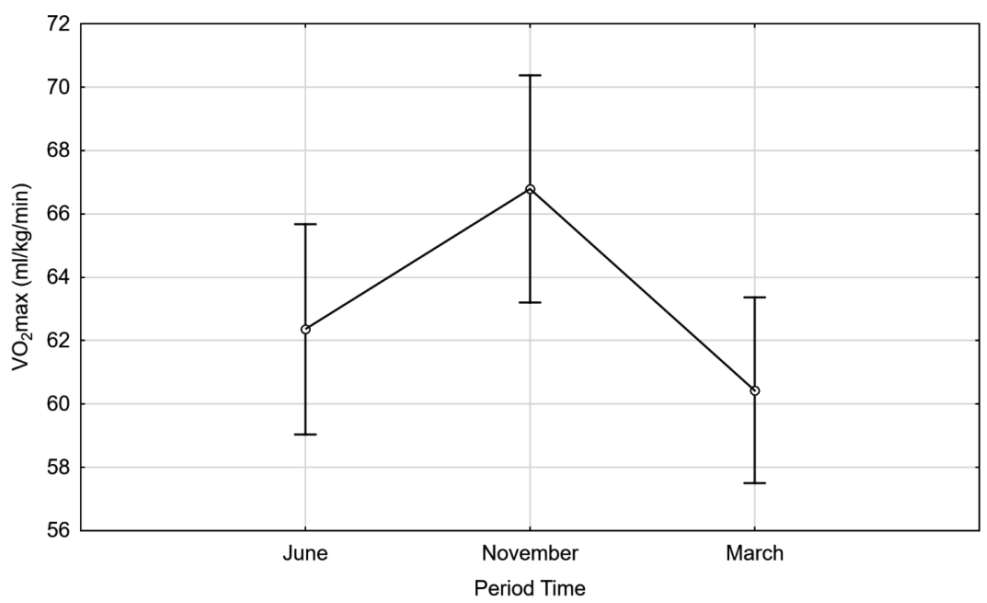

Figure 1 Participants' $\mathrm{VO}_{2 \max }[\mathrm{ml} / \mathrm{kg} / \mathrm{min}]$ by training period

Table 2: Changes in the statistical significance of $\mathrm{VO}_{2 \max }[\mathrm{ml} / \mathrm{kg} / \mathrm{min}]$ between training periods

\begin{tabular}{|l|c|c|c|c|}
\hline \multirow{2}{*}{ Training period } & \multicolumn{4}{|c|}{ Tukey HSD test } \\
\cline { 2 - 5 } & & 1. June & 2. October & 3. March \\
\hline 1. June & $\mathrm{VO}_{2 \max }[\mathrm{ml} / \mathrm{kg} / \mathrm{min}]$ & & 0.058525 & 0.552844 \\
\hline 2. October & $\mathrm{VO}_{2 \max }[\mathrm{ml} / \mathrm{kg} / \mathrm{min}]$ & 0.058525 & & $0.005235^{*}$ \\
\hline 3. March & $\mathrm{VO}_{2 \max }[\mathrm{ml} / \mathrm{kg} / \mathrm{min}]$ & 0.552844 & $0.005235^{*}$ & \\
\hline
\end{tabular}

\footnotetext{
* statistically significant at $\mathrm{p}=0.005$
}

According to fig. 2 and tab. 1, 3 the highest $\mathrm{HR}_{\max }$ occurred in November (196 bpm), somewhat lower in the early preparation period $(193 \mathrm{bpm})$, and the lowest $(188 \mathrm{bpm})$ in the weeks directly preceding the competition period. The second and third values are statistically significantly different $(\mathrm{p}=0.005)$. 


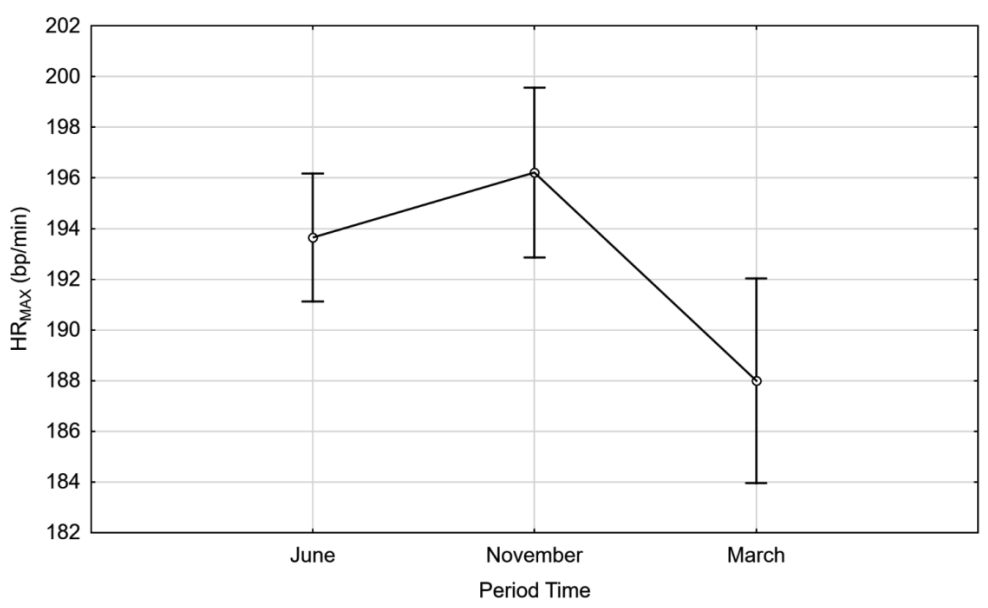

Figure 2: Participants' $\mathrm{HR}_{\max }[\mathrm{bpm}]$ by training period

Table 3: Changes in the statistical significance of $\mathrm{HR}_{\max }[\mathrm{bpm}]$ between training periods

\begin{tabular}{|l|l|l|l|l|}
\hline \multirow{2}{*}{ Training period } & \multicolumn{4}{|c|}{ Tukey HSD test } \\
\cline { 2 - 5 } & & 1. June & 2. October & 3. March \\
\hline 1. June & $\mathrm{HR}_{\text {max }}[\mathrm{ud} / \mathrm{min}]$ & & 0.05713 & $0.000163^{*}$ \\
\hline 2. October & $\mathrm{HR}_{\text {max }}[\mathrm{ud} / \mathrm{min}]$ & 0.05713 & & $0.000129^{*}$ \\
\hline 3. March & $\mathrm{HR}_{\max }[\mathrm{ud} / \mathrm{min}]$ & $0.000163^{*}$ & $0.000129^{*}$ & \\
\hline
\end{tabular}

* statistically significant at $\mathrm{p}=0.005$

$\mathrm{VE}$ is similar to the first two indicators of aerobic capacity (fig. 3 and tab. 1, 4) in that its value is also the highest in November [161 1/min]. The June and March values of VE are comparable: 154.9 and $154.7 \mathrm{l} / \mathrm{min}$, respectively. The differences between first and second measurements of $\mathrm{VE}$ and between the second and third measurements are statistically significant $(\mathrm{p}=0.005)$.

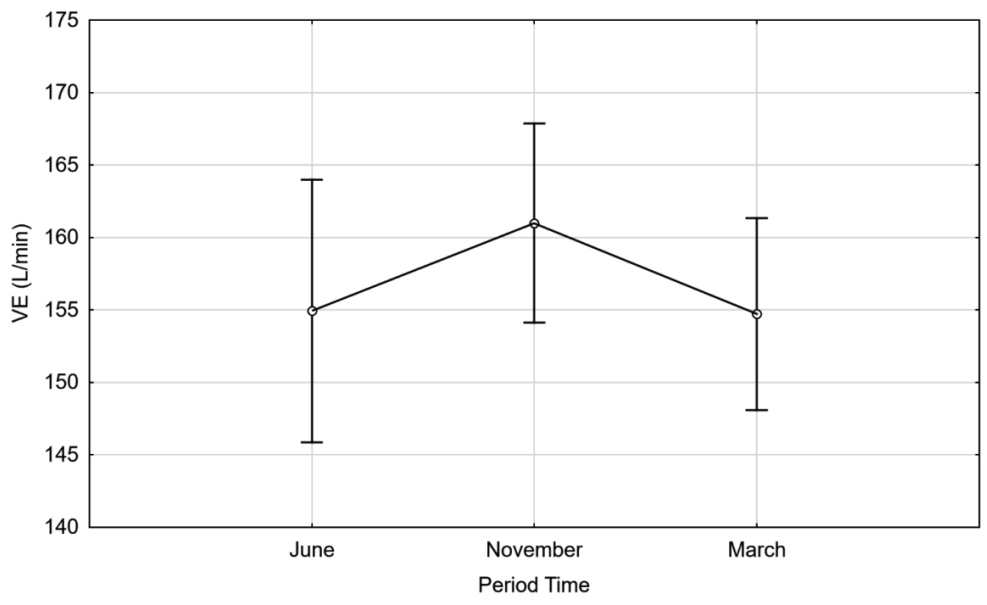

Figure 3 Participants' VE [l/min] by training period 
Table 4: Changes in the statistical significance of VE [l/min] between training periods

\begin{tabular}{|l|c|c|c|c|}
\hline \multirow{2}{*}{ Training period } & \multicolumn{4}{|c|}{ Tukey HSD test } \\
\cline { 2 - 5 } & & 1. June & 2. October & 3. March \\
\hline 1. June & VE $[1 / \mathrm{min}]$ & & $0.002658^{*}$ & 0.990533 \\
\hline 2. October & VE $[1 / \mathrm{min}]$ & $0.002658^{*}$ & & $0.001932^{*}$ \\
\hline 3. March & VE $[1 / \mathrm{min}]$ & 0.990533 & $0.001932^{*}$ & \\
\hline
\end{tabular}

* statistically significant at $\mathrm{p}=0.005$

Figure 4 and tab. 1, 5 show Wtot values $[\mathrm{J} / \mathrm{kg}]$ recorded in participants in different periods of the annual macrocycle. The values form an upward trend, rising from $125.97[\mathrm{~J} / \mathrm{kg}]$ in the early preparation period to $126.39[\mathrm{~J} / \mathrm{kg}]$ in the competition period. The highest value of Wtot, $136.26[\mathrm{~J} / \mathrm{kg}]$, was recorded in the run-up to the World Championship. The differences between the first and second measurements of Wtot and between the second and third measurements are statistically significant $(\mathrm{p}=0.005)$.

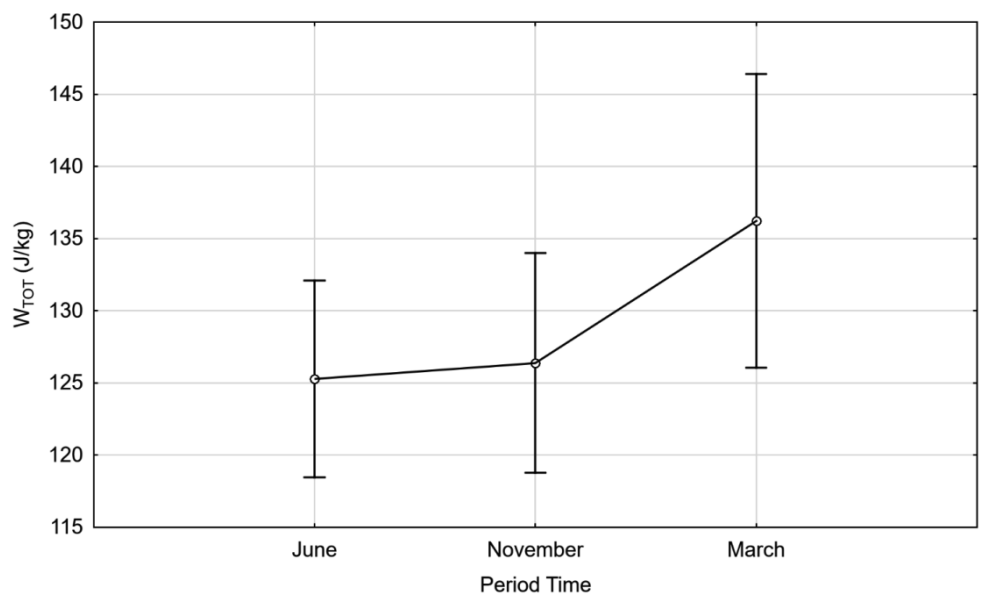

Figure 4 Participants' $\mathrm{W}_{\text {tot }}[\mathrm{J} / \mathrm{kg}]$ by training period

Table 5: Changes in the statistical significance of $W_{\text {tot }}[\mathrm{J} / \mathrm{kg}]$ between training periods

\begin{tabular}{|l|c|c|c|c|}
\hline \multirow{2}{*}{ Training period } & \multicolumn{4}{|c|}{ Tukey HSD test } \\
\cline { 2 - 5 } & & 1. June & 2. October & 3. March \\
\hline 1. June & $\mathrm{W}_{\text {tot }}[\mathrm{J} / \mathrm{kg}]$ & & 0.710632 & $0.000129^{*}$ \\
\hline 2. October & $\mathrm{W}_{\text {tot }}[\mathrm{J} / \mathrm{kg}]$ & 0.710632 & & $0.00013^{*}$ \\
\hline 3. March & $\mathrm{W}_{\text {tot }}[\mathrm{J} / \mathrm{kg}]$ & $0.000129^{*}$ & $0.00013^{*}$ & \\
\hline
\end{tabular}

* statistically significant at $\mathrm{p}=0.005$

According to the data in fig. 5 and tab. 1, 6 the level of Pmax [W] showing participants' anaerobic capacity was the lowest in the preparation period $-988 \mathrm{~W}$. By the second measurement its value rose to 1037.5 [W], to be the highest in the direct preparation period (DPP) - 1070.7 [W]. The differences between the first and third measurements of Pmax and between the second and third measurements are statistically significant $(p=0.005)$. 


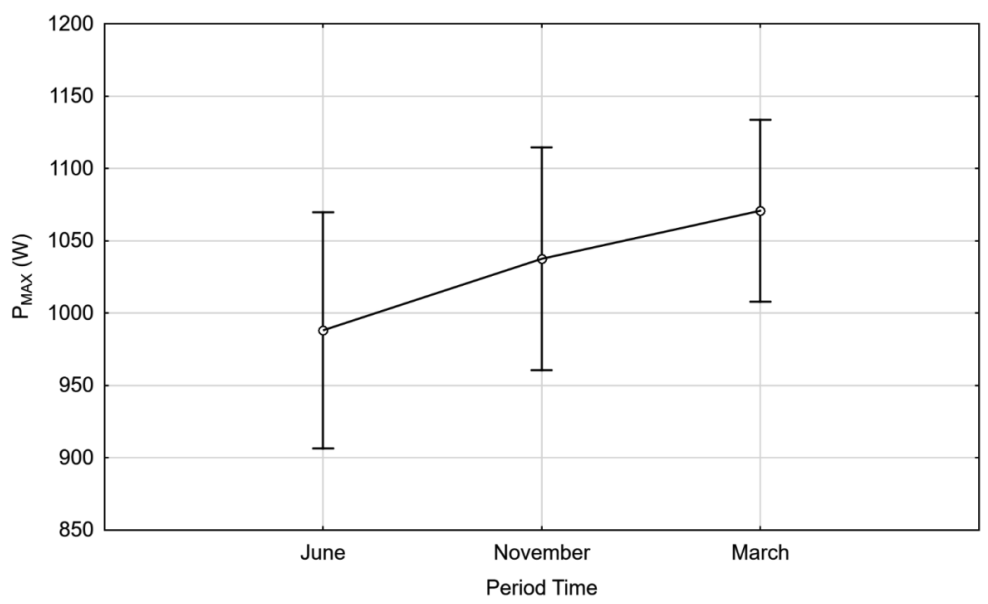

Figure 5 Participants' $P \max [\mathrm{W}]$ by training period

Table 6: Changes in the statistical significance of Pmax [W] between training period

\begin{tabular}{|l|c|c|c|c|}
\hline \multirow{2}{*}{ Training period } & \multicolumn{4}{|c|}{ Tukey HSD test } \\
\cline { 2 - 5 } & & 1. June & 2. October & 3. March \\
\hline 1. June & $\mathrm{P}_{\max }[\mathrm{W}]$ & & $0.005256^{*}$ & $0.000138^{*}$ \\
\hline 2. October & $\mathrm{P}_{\max }[\mathrm{W}]$ & $0.005256^{*}$ & & 0.069661 \\
\hline 3. March & $\mathrm{P}_{\max }[\mathrm{W}]$ & $0.000138^{*}$ & 0.069661 & \\
\hline
\end{tabular}

* statistically significant at $\mathrm{p}=0.005$

As the data in fig. 6 and tab. 1, 7 show, participants' Pmax [W/kg] increased during the annual training cycle, from $13.1[\mathrm{~W} / \mathrm{kg}$ ] in June to $14.1[\mathrm{~W} / \mathrm{kg}]$ in October and $14.7[\mathrm{~W} / \mathrm{kg}]$ in March before the World Championship. The differences between the first and second measurements of Pmax and between the first and second measurements are statistically significant $(p=0.005)$.

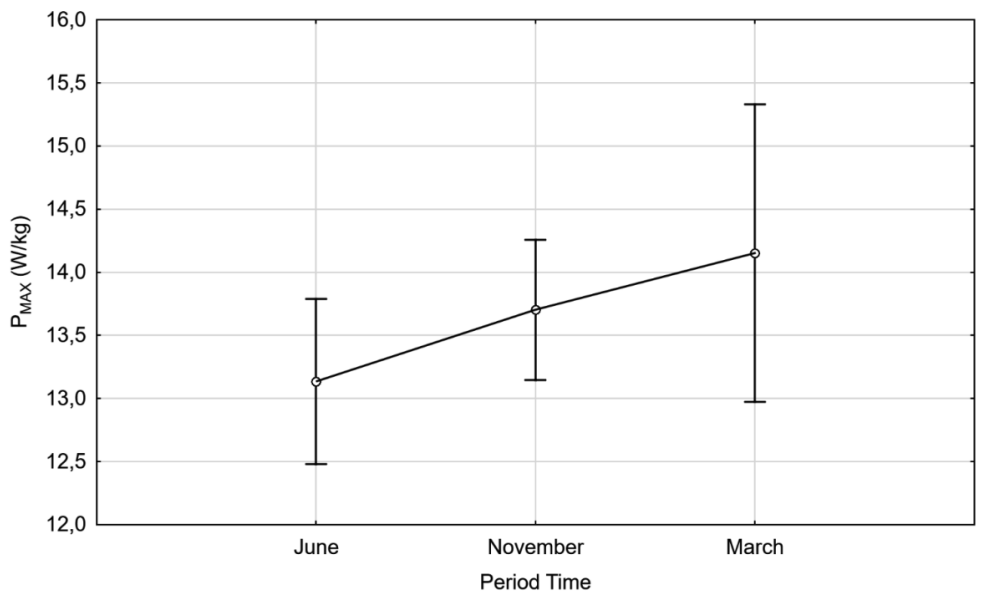

Figure 6 Participants' $\operatorname{Pmax}[\mathrm{W} / \mathrm{kg}]$ by training periods 
Table 7: Changes in the statistical significance of Pmax [W/kg] between training periods

\begin{tabular}{|l|l|c|c|c|}
\hline \multirow{2}{*}{ Training period } & \multicolumn{4}{|c|}{ Tukey HSD test } \\
\cline { 2 - 5 } & & 1. June & 2. October & 3. March \\
\hline 1. June & Pmax $[\mathrm{W} / \mathrm{kg}] \_V I I$ & & 0.091447 & $0.001658^{*}$ \\
\hline 2. October & Pmax $[\mathrm{W} / \mathrm{kg}]$ _VIII & 0.091447 & & 0.209238 \\
\hline 3. March & Pmax $[\mathrm{W} / \mathrm{kg}]$ _IX & $0.001658^{*}$ & 0.209238 & \\
\hline
\end{tabular}

*statistically significant at $\mathrm{p}=0.005$

The values of Wtot $\mathrm{J} / \mathrm{kg}$ showing subjects' anaerobic capacity are presented in fig. 7 and tab. 1, 8 below. The lowest Wtot, 301 [W/kg], was recorded in June. By November it increased to 311 [W/kg] and its highest value was noted in the run-up to the World Championship - 348 [W/kg]).

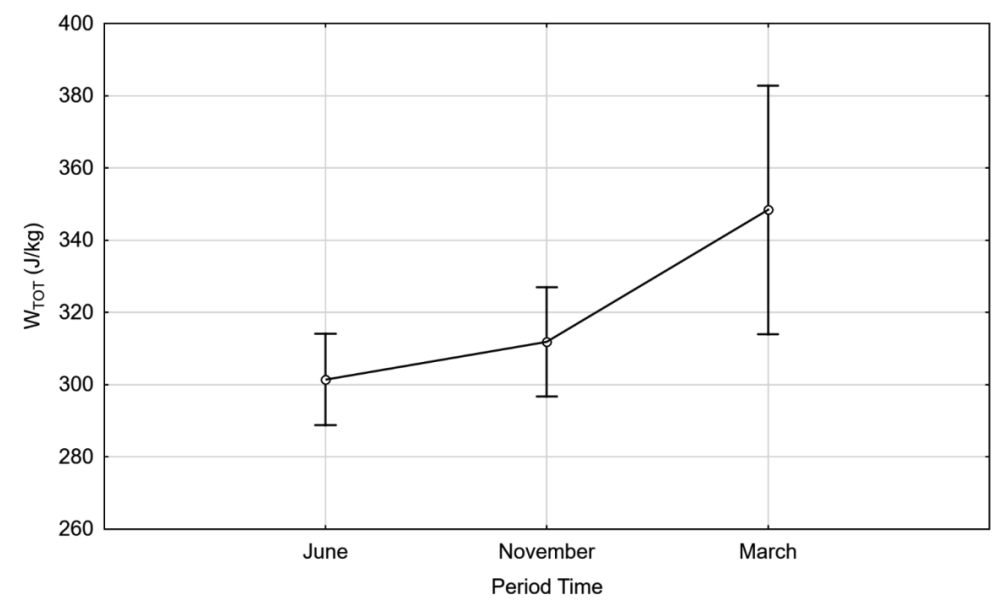

Figure 7 Participants' Wtot $[\mathrm{W} / \mathrm{kg}]$ by training period

Table 8: Changes in the statistical significance of Wtot $[\mathrm{W} / \mathrm{kg}]$ between training periods

\begin{tabular}{|l|c|c|c|c|}
\hline \multirow{2}{*}{ Training period } & \multicolumn{4}{|c|}{ Tukey HSD test } \\
\cline { 2 - 5 } & & 1. June & 2. October & 3. March \\
\hline 1. June & Wtot W/kg VII & & 0.499772 & $0.000187^{*}$ \\
\hline 2. October & Wtot W/kg VIII & 0.499772 & & $0.001444^{*}$ \\
\hline 3. March & Wtot W/kg IX & $0.000187^{*}$ & $0.001444^{*}$ & \\
\hline
\end{tabular}

*statistically significant at $\mathrm{p}=0.005$

\section{DISCUSSION}

The values of $\mathrm{VO}_{2 \max }$ (a key indicator of aerobic capacity) have been investigated in ice hockey players with different levels of athletic competence and doing training according to different programmes in a number of studies [Volkov et al. 1984]. They have shown that aerobic capacity $\left(\mathrm{VO}_{2 \max }\right)$ and the level of athletic competence are inversely related to each other. The $\mathrm{VO}_{2 \max }$ of young athletes covered by training programmes emphasising general preparation exercises based on aerobic metabolism exceeds $60 \mathrm{ml} \cdot \mathrm{kg}^{-1} \cdot \mathrm{min}^{-1}$. In athletes with extensive training experience who do mostly special preparation exercises $\mathrm{VO}_{2 \max }$ is lower by $10 \%$ compared with its values typically 
noted in younger ice-hockey players [Gabrys 2000]. A considerable increase in the proportion of exercises involving anaerobic lactate metabolism is followed by declining levels of power and aerobic capacity indicators [Starsi et al.1999]. The rate of changes in metabolism induced by high-intensity anaerobic exercises depends on the efficiency of aerobic metabolism. The $\mathrm{VO}_{2 \max }$ of ice-hockey players falling to $50 \mathrm{ml} \cdot \mathrm{kg}^{-1} \cdot \mathrm{min}^{-1}$ makes more difficult for them to do sport-specific training in the special preparation period and pre-competition period and perform during games, as well as making them more prone to overtraining because of uncompensated fatigue.

Among the 18-year old ice-hockey players who entered the NHL draft in the years 2001-2003, $50 \%$ (123 athletes) had $\mathrm{VO}_{2 \max }$ equal to or higher than $57 \mathrm{ml} \cdot \mathrm{kg}^{-1} \cdot \mathrm{min}^{-1}$. In only $10 \%$ was $\mathrm{VO}_{2 \max }$ below $50 \mathrm{ml} \cdot \mathrm{kg}^{-1} \cdot \mathrm{min}^{-1}$. The mean $\mathrm{VO}_{2 \max }$ values of players entering successive drafts in the next three years were within a narrow range of 55.1 to $60.4 \mathrm{ml} \cdot \mathrm{kg}^{-1} \cdot \mathrm{min}^{-1}$, which implies that the range can be deemed the minimum reference range of aerobic capacity of an 18-year old ice-hockey player [Szmatlan-Gabrys 2007]. Interestingly, the draft entrants' $\mathrm{VO}_{2 \max }$ was not found to be related to their position. A notable finding was the high aerobic capacity $\left(\mathrm{VO}_{2 \max }\right)$ of goalkeepers $(\geq 56 \mathrm{ml}$. $\left.\mathrm{kg}^{-1} \cdot \mathrm{min}^{-1}\right)$. The information should be taken account of in designing goalkeeper training, which should aim to not only to maintain but also to enhance the aerobic capacity of young ice-hockey players so that they can better perform in the future [Szmatlan-Gabrys 2007].

To be effective during ice-hockey games and to cope with training loads, a player must be able to derive energy from anaerobic glycolysis. During an on-ice game of up to 30-40 sec and during training activity of up to $180 \mathrm{sec}$, anaerobic metabolism and aerobic metabolism generate $40-60 \%$ and $10-90 \%$ of energy, respectively. For a player to be able to work in this exercise zone, very comprehensive training is required [Szmatlan-Gabrys 2007]. During a game, 69\% of the player's energy comes from anaerobic metabolism accompanied by oxygen debt of up to 8.5-9.6 1 and an increase in blood lactate concentration to $8-14 \mathrm{mmol}^{-1}{ }^{-1}$ [Gabrys et al. 2000, Szmatlan-Gabrys 2007]. Periods of continuous work (i.e. without rests) range in duration from 10 to $55 \mathrm{~s}$ (ca. $40 \mathrm{sec}$ on average). The main source of energy is then anaerobic lactate metabolism [Horsky 1977, Gabrys et al. 2004]. Blood lactate concentration increases from 8 to $14 \mathrm{mmol}^{-1}$, an equivalent of $50-75 \%$ of its maximum level. The results of Czech ice-hockey players on the Wingate test [Gabrys 2000], which is also used in Canadian ice hockey to measure players' anaerobic capacity, showed that high anaerobic capacity is not only important but also that its importance increases with the level of athletic competence.

The $\mathrm{P}_{\max }$ values of the members of the Canadian Olympic national team have been presented, inter alia, by Watson and Sergeant [1986]. A comparison showed that they were not different from the $\mathrm{P}_{\max }$ values of Polish ice-hockey players obtained 15 years later [Szmatlan-Gabrys 2007].

In Vescovi et al. [2006a], the Wingate test was presented as a tool enabling the evaluation of players entering the NHL draft. The $\mathrm{P}_{\max }$ values obtained for 18-year-old draft entrants ranged from 11.9 to $12.4 \mathrm{~W} / \mathrm{kg}$ of body mass, so they were lower than average $\mathrm{P}_{\max }$ values calculated for the members of Poland's under 18 national ice hockey team in this study. Farlinger et al. [2007] had young hockey players perform the Wingate test some 3 weeks from the end of the competition period. Their $\mathrm{P}_{\max }$ and total work values $(13.4= \pm 1.8 \mathrm{~W} / \mathrm{kg}$ and $300 \mathrm{~J} / \mathrm{kg}$, respectively $)$ were comparable with those obtained in this study in the early phase of the preparation period (June). In Peterson et al. [2016], who also conducted their study in June, the $P_{\max }$ values of university ice hockey players varied within 12.7-.2.9 W/kg and were slightly lower compared with those calculated in this study in the same training period.

The above comparative analysis of changes in the anaerobic capacity of young ice-hockey players, members of the Polish U-18 national team, over a 7-month preparation period for the 2003 World Championship, Szmatlan-Gabrys [2007] showed that: 
- the values of power and total work parameters recorded in the first competition period (September-December) were considerably higher than those obtained after the special preparation period;

- increases in $\mathrm{P}_{\max }$ and Wtot levels between September and December were accompanied by more effective use of anaerobic glycolysis which is the main metabolic source of energy for this type of effort - a smaller increase in LA co-existed with rising values of ergonometric parameters;

- as the intensity of competition (games) increased, the effectiveness of anaerobic metabolism grew smaller. The values of ergonometric parameters remained steady, but energy expenditure increased (the values of $\mathrm{LA}_{\max }$ and deltaLA increased and $\mathrm{P}_{\max }$ and Wtot did not change).

\section{CONCLUSION}

1. The values of three of the four analysed aerobic capacity indicators were the lowest in the direct preparation period and the highest in the early competition period.

2. The fact that Wtot values obtained during the incremental exercise test were the highest in the direct preparation period implies that the participants were the most effective athletically in the run-up to the main sporting event of a season (the World Championship).

3. The values of all anaerobic capacity indicators were the highest in the direct preparation period which means that the participants were well prepared to cope with the specific demands of on-ice competition.

4. The monitoring of training processes focused on the analysed parameters will allow coaches and players to adjust the volume and intensity of training to its goals.

\section{References}

Bar-Or O. 1981. The Wingate Anaerobic Test. Characteristics and applications. Symbioses, 13, 157-172.

Battochio R. C., Schinke R. J., Battochio D. L., Halliwel W., Tenenbaum G. 2009. An Examination of the Challenges Experienced by Canadian Ice- Hockey Player since the National Hockey Leauge. Journal of Clinical Sports Psychology: 3, $267-285$.

Borek Z. 2011. Wielkość i struktura obciążeń treningowych w trzyletnim makrocyklu szkoleniowym młodocianych zawodników w hokeju na lodzie. Uniwersytet Ekonomiczny Kraków.

Burr J. F., Jamnik R., Baker J. Macpherson A., Gledhill N., Mcgiure E. L. 2008. Relationship of physical fitness test results and hockey playing potential in elite-level ice hockey players. Journal of Strength and Conditioning Research, 22(5), 1535-1543. National Strength and Conditioning Association.

Carey D. G., Drake M. M., Pliego G. J., Raymond R. L. 2007. Do jockey players Reed aerobic fitness> Relation Beetwen $\mathrm{VO}_{2}$ max and fatigue Turing hihg-intensity intermittent ice skating. 21 (3), 963-966. National Strength and Conditioning Association.

Durocher J. J., Leeten D. T., Carter J. C. 2008. Sport-specific assessment of lactate threshold and aerobic capacity throughout a collegiate hockey season. Appl. Physiol. Nutr. Metab. 33: 1165-1171.

Durocher J. J., Guisfredi A. J., Leetun D. T., Carter J. C. 2010. Comparison of on-ice and off-ice graded Exercise testing in collegiate hockey players. Appl. Physiol. Nutr. Metab. Vol. 35.

Geithner Ch. A., Lee A. M., Bracko M. R. 2006. Physical and performance differences among forwards, defensemen, and goalies in elite women's ice hockey. Journal of Strength and Conditioning Research, 20(3), 500-505.

Leone M., Legar L. A., Lariviera G., Comtois A. S. 2007. An On-Ice Aerobic Maximal Multistage Shuttle Skate Test for Elite Adolescent Hockey Players. Int J Sports Med. 28: 823-828.

Farlinger C. M., Kruisselbrink L. D., Fowles J. R. 2007. Relationships to skating performance in competitive hockey players. J. Strength Cond. Res. 21(3): 915-922.

Gabrys T. 2000. Wydolność beztlenowa sportowców. Trening, kontrola, wspomaganie. AWF. Katowice. s. 320.

Gabrys T., Borek Z., Szmatlan-Gabrys U., Gromisz W. 2004. Test Wingate. Wybrane zagadnienia diagnostyki w sporcie wyczynowym. ZSP, Alma-Press. Warszawa. S. 235.

Gabrys T., Bottoms L., Stanula A. 2009. The evaluation of intensity In ice-hockey game - the players individual analysis. [W:] Suss V., Buchtel J. at all. Hodnoceni herniho vykonu ve sportovnich hrach. Univerzita Karlova v Praze. Karolinum. s. 113-126. ISBN 978-80-246-1680-3. 
Gilenstam K. M., Thorsen K., Henriksson-Larsen K. B. 2011. Physiological correlates of skating performance in women's and men's ice jockey. Journal of Strength and Conditioning Research, 25(8)/2133-2142.

Horsky L. 1977. Trening v ladovym hokeji. Sport. Bratislava.

Matthews M. J., Comfort P., Crebin R. 2010. Complex training in ice hockey: The effects of a heacy resisted sprint on subsequent ice-hockeysprint performance. Journal of Strenght and Conditioning Research 24(11), 2883-2887. National Strength and Conditioning Association.

Noonan B. C. 2010. Intagrame blond-lactate values Turing ice jockey and their relationships to commonly used jockey and their relationships to commonly used jockey testing protocol. Journal of Strenght and Conditioning Association. 24(9). 2290-2295. National Strength and Conditioning Association.

Nowakowska M., Gabrys T., Ozimek M., Stanula A., Szmatlan-Gabrys U. 2017. Wysiłek fizyczny, obciążenia treningowe i startowe a zmienność wskaźników psychomotorycznych u hokeistów na lodzie. Zeszyt 73. Prace Naukowo-Metodyczne PWSZ w Krośnie. Państwowa Wyższa Szkoła Zawodowa w Krośnie. Mazowieckie Centrum Poligrafii, Marki.

Peterson B. J., Fitzgerald J. S., Dietz C. C., Ziegler K. S., Baker S. E., Snyder E. M. 2016. Off-ice anaerobic power does not predict on-ice repeated shift performance in hockey. Journal of Strength and Cinditioning Research 30(9): 2375-2381.

Ransdel L. B., Murray T. M., Gao Y. 2013. Off-ice fitness of elite female ice hockey players by team success, age, and player position. Journal of Strength and Cinditioning Research 27(4), 875-88. National Strength and Conditioning Association.

Szmatlan-Gabryś U. 2007. Fizjologiczne i biologiczne podstawy treningu na lodzie. Monografia Warszawa. PZHL.

Starsi J., Jancokova L, Vyboh A. 1999. Teoria a didaktika ledoveho hokeja. Univ. M. Bela, Banska Bystrica

Vescovi J. D., Murray T. M., Fiala K. A., VanHeest J. L. 2006a. Off-Ice Performance and Draft status of Elite Ice Hockey Players. International Journal of Sports Physiology and Performance. 1: 207-221. Human Kinetics, Inc.

Vescovi J. D., Murray T. M., VanHeest J. L. 2006b. Positional Performance Profiling of Elite Ice Hockey Players. International Journal of Sports Physiology and Performance. 1: 84-94.

Volkov N., Bukatin A., Sarsanin G., Melichowa S., Cerkov W. 1982. Specialnaja wynosliwost hokeistow. Fizkultura i Sport, Moscow.

Watson R., Sargeant T, 1986. Laboratory and On-Ice Test Comparisons of Anaerobic Power of Ice Hockey Players Can. J. Appl. Physiol. Vol. 11, No. 4: 218-224. 